deficiencies of cobalt (bush sickness of New Zealand, pining in the United Kingdom, etc.); of copper (swayback in the United Kingdom and other countries, which is a disease of lambs with paralysis of the limbs, inco-ordination and demyelination of cer. tain tracts of the spinal cord, which J. R. M. Innes (Vet. Record, 55, 369; 1943) has compared with certain rare diseases of man); of both copper and cobalt; and of potassium, sodium chlorine, iodine, phosphorus, caleium or magnesium (grass or lactation tetany). Other sections deal with diseases attributed or attributable to excesses of selenium, molybdenum, nitrate or manganese and with fluorosis and arsenical poisoning. A useful general summary. completes the review, and the bibliographies of each section guide the reader to further study. The problems here discussed are difficult and are not for those who require circumscribed investigations which are certain to give results. Miss Russell has performed very well her difficult task of presenting the controversial literature about them, and everyone who is concerned with this kind of work will be grateful to her.

\section{Mexico's Vital Statistics}

Dr. Ricardo Granillo, head of the Mexican Department of Statistics and Demography, states that his Department is a part of the Secretariat of National Economy (Bol. Of. San. Panamericana, 23, 419 ; 1944). It collects and publishes statistics, takes a national census, makes special studies, represents the country at international congresses, and has jurisdiction over population, public educa. tion, social welfare, industrial economy and vital statistics. The principal, functions of the Vital Statistics Office of the Secretariat of Health and Welfare include keeping Federal and State health authorities informed of the general mortality and that from contagious disease and other important causes; reporting on epidemics in areas where there are no practitioners and regular reports of contagious diseases cannot be obtained; the study of the geographical and seasonal distribution of general, infant, endemic and epidemic disease mortality; reporting to the Panamerican Sanitary Bureau and other international offices and neighbouring health authorities on the general health conditions of Mexico; and keeping a record of public health activity throughout the Republic.

\section{Nizamiah Observatory, Hyderabad}

THe director of the Nizamiah Observatory has communicated a paper, "Occultations of Stars and Planets by the Moon observed at the Nizamiah Observatory, Hyderabad, during the Year 1943" (Mon. Not., Roy. Astro. Soc., 104, 4 ; 1944), which gives the occultation results for 1943 from January 11 until December 31. Twenty-seven occultations of stars and one of Venus were observed by M. K. Bappu, using the 15-in. visual refractor. M. V. V. Sastry, assisted by S. Aravamudan, carried out the reductions. In the case of two stars, proper motions were applied to the co-ordinates given in the catalogue in computing the mean places for use in the reductions, and positions were taken from the "Nautical Almanac" for the others.

\section{The Night Sky in January}

New moon occurs on January 14d. 05h. 06m., U.T., and full moon on January 26d. 06h. 41m. The following conjunctions with the moon take place: Jan. 4d. 20h., Jupiter $4^{\circ}$ S. ; Jan. 12d. 08h., Mercury $0.2^{\circ}$ S. ; Jan. 12d. 21h., Mars $2^{\circ}$ S.; Jan. 17d. 14h., Venus $4^{\circ}$ N. ; Jan. 25 d. 18 h., Saturn $0.5^{\circ}$ N. Mercury is in conjunction with Mars on Jan. 26d. 15h., Mercury being $0.4^{\circ} \mathrm{N}$. The following occultations of stars brighter than magnitude 6 take place: Jan. 1d. 20 h. $56 \cdot 5 \mathrm{~m} ., 8$ Leon, $(R)$; Jan. 18 d. $17 \mathrm{~h} .52 \cdot 8 \mathrm{~m}$., 33 Pisc. $(D)$; Jan. 21d. 17h. 27.5m., $\mu$ Ceti $(D)$; Jan. 24d. 2h. $15 \cdot 2 \mathrm{~m}$, $i$ Taur. $(D)$; Jan. $25 \mathrm{~d}$. $2 \mathrm{~h}$. $21 \cdot 7 \mathrm{~m}$. , $+20^{\circ} 1105 \mathrm{~m}(D)$; Jan. 26d. 18h. $24 \cdot 0 \mathrm{~m}$., 63 Gemi. $(D)$. The times refer to the latitude of Greenwich, and $D$ and $R$ refer to disappearance and reappearance, respectively. Mercury rises $1 \frac{1}{2}$ hours before the sun at the beginning, and 36 minutes before the sun at the end, of the month. It is stationary on Jan. 2 and reaches its greatest westerly elongation on Jan. 13. Venus is conspicuous in the evening hours, setting at $19 \mathrm{~h} .5 \mathrm{~lm} ., 20 \mathrm{~h} .29 \mathrm{~m}$. and $21 \mathrm{~h} .08 \mathrm{~m}$. at the beginning, middle and end of the month, respectively. Mars rises about three-quarters of an hour before the sun at the beginning of the month and is not well placed for observation. Jupiter, in the constellation of Virgo, is a conspicuous object in the morning hours and rises at $23 \mathrm{~h}$. and $2 \mathrm{lh}$. at the beginning and end of the month, respectively. Saturn, in the constellation of Gemini, can be seen throughout the night, setting at $6 \mathrm{~h} .52 \mathrm{~m}$. in the middle of the month.

\section{Announcements}

Dr. W. A. WATERS, lecturer in chemistry in the University of Durham, has been elected to an official fellowship in organic chemistry at Balliol College, Oxford.

Mr. A. W. Ladner retired from his position of principal of the Marconi Company's School of Wireless Communication at the end of the year, after thirty-two years service with the Company, and twenty-four years as superintendent of instruction: Mr. Ladner will continue to act in an advisory capacity. His place as principal of the School has been taken by Mr. N. C. Stamford, who was previously with the Company and has since been on the teaching staff of the Department of Electrical Engineering at the University of Manchester.

AT the annual meeting of the Genetical Society, the following officers were elected: President, Dr. C. D. Darlington; Vice-Presidents, Prof. T. J, Jenkin, Prof. R. A. Fisher and Mr. M. B. Crane; Treasurer, Miss E. R. Saunders; Secretaries, Mr. W. J. C. Lawrence, John Innes Horticultural Institution, Merton, S.W.19, and Mr. R. Race, Galton Laboratory. Serum Unit, Department of Pathology, Cambridge.

THE following appointments have recently been made in the Colonial Agricultural Service: V. E. Gale, to be agricultural officer, Nigeria; D. H. Lay. cock, to beagricultural officer, Nyasaland; A.H. Strickland, to be entomologist, Gold Coast; J. W. D. Fisher, senior agricultural officer, Sierra Leone, to be principal agricultural officer, Sierra Leone; R. R. Glanville, principal agricultural officer, Nigeria, to be director of agriculture, Sierra Leone; and R. 0 . Williams, deputy director of agriculture, Trinidad, to be director of agriculture, Zanzibar.

Erratum.-In the article on the "Deciduous Cypress" in Nature of December 16, p. 775, for $12 \mathrm{ft}$. (line 8, col. 2) read $21 \mathrm{ft}$. 